\title{
KARAKTERISTIK PERJANJIAN PEMBIAYAAN OLEH PERUSAHAAN PEMBIAYAAN MULTIGUNA
}

\author{
Oleh: \\ Syahrul Ramadhan \\ Email : buyung.arul17@gmail.com \\ Universitas Jember \\ Herowati Poesoko \\ Email : poesokoherowati.fh@unej.ac.id \\ Universitas Jember \\ Ermanto Fahamsyah \\ Email: ermanto_fahamsyah@yahoo.co.id \\ Universitas Jember
}

\begin{abstract}
Abstrak
Perusahaan Pembiayaan Multiguna dalam Pasal 1 angka 1 Peraturan Otoritas Jasa Keuangan Nomor 29/POJK.05/2014 Tentang Penyelenggaraan Usaha Perusahaan Pembiayaan (untuk selanjutnya disebut POJK No 29/POJK.05/2014) adalah badan usaha yang melakukan kegiatan pembiayaan untuk pengadaan barang dan/atau jasa. Terkait itu pada pasal 18 ayat (2) POJK No 29/POJK.05/2014 yang mengatur tentang mitigasi risiko tidak ada norma tertulis yang membolehkan pembebanan jaminan Hak Tanggungan, namun manakala membaca penafsiran otentiknya memperluas norma yang sifatnya limitatif karena ada frase dapat dilakukan selain yang tertulis dalam pasal 18 ayat (2). Kekaburan norma itu berimplikasi pada adanya penyimpangan hukum yaitu dengan melakukan pembebanan Hak Tanggungan. Perjanjian Pembebanan Hak Tanggungan dalam pembiayaan multiguna tidak sesuai dengan karakteristik perjanjian pembiayaan oleh Perusahaan Multiguna.
\end{abstract}

Kata kunci: Penyimpangan Hukum, Kekaburan Norma, Perjanjian Pembiayaan Multiguna

\begin{abstract}
Multipurpose Financing Company in Article 1 number 1 Financial Services Authority Regulation Number 29 / POJK.05 / 2014 concerning Business Conduct of Financing Companies (hereinafter referred to as POJK No 29 / POJK.05 / 2014) is a business entity that carries out financing activities for the procurement of goods and / or services. Related to that, in article 18 paragraph (2) POJK No 29 / POJK.05 / 2014 which regulates risk mitigation there is no written norm that allows the imposition of guarantees of Mortgage Rights, but when reading the authentic interpretation expands the norms that are limitative because there are phrases that can be done in addition to written in article 18 paragraph (2). This vagueness of norms has implications for legal deviation, namely by imposing Mortgage Rights. The Collateral Placement Contract in multipurpose financing is not in accordance with the characteristics of the financing contract by the Multipurpose Company.
\end{abstract}

Keywords: Legal Deviation, Vague Norms, Multipurpose Financing Contract

JURNAL RECHTENS, Vol. 9, No. 2, Desember 2020 


\section{PENDAHULUAN}

\subsection{Latar Belakang}

Perkembangan lembaga pembiayaan di Indonesia cukup pesat ${ }^{1}$. Keberadaan lembaga pembiayaan semakin diminati oleh masyarakat. Misalnya pembiayaan konsumen, banyak diminati oleh masyarakat karena relatif tidak sulit prosedurnya. Terkait itu semakin diperkuat dengan lahirnya POJK No. 29/POJK.05/2014 mengalami perluasan kegiatan usaha. Perluasan kegiatan usaha pada Perusahaan Pembiayaan meliputi pembiayaan investasi, pembiayaan modal kerja, pembiayaan multiguna, dan pembiayaan yang mendapatkan persetujuan Otoritas Jasa Keuangan (untuk selanjutnya disebut OJK). Pada prinsipnya suatu pembiayaan terkait dengan suatu jaminan agar tercipta kepastian hukum yang dituangkan dalam perjanjian.

Perjanjian pembiayaan oleh Perusahaan Pembiayaan memiliki karakter yang khas. Terkait itu bisa dilihat dari sistem hukumnya, objek perjanjian pembiayaan, dan pihak-pihak yang terkait dalam perjanjian pembiayaannya. Beberapa Perusahaan multiguna di Indonesia jika dilihat dibeberapa situs websitenya penulis temukan Pembiayaan oleh perusahaan multiguna yang Jaminannya Sertipikat Hak Atas

1 Rudyanti Dorotea Tobing, Hukum lembaga Pembiayaan Asas Keadilan dalam Perjanjian Pembiayaan, Laksbangpressindo, Surabaya, 2017, hlm. 3 .
Tanah. Adira memberikan pembiayaan multiguna dengan agunan sertipikat hak atas tanah. ${ }^{2}$ MPM Finance menyediakan pembiayaan untuk memenuhi modal kerja maupun investasi produktif lainnya melalui pembiayaan dengan jaminan properti (baik berupa sertifikat tanah, rumah, gedung, pabrik, apartemen, ruko, dll). ${ }^{3}$ BFI Finance Indonesia menyediakan pembia-yaan untuk modal usaha dengan jaminan Sertipikat Hak Milik Atas Tanah. ${ }^{4}$ Terkait itu juga penulis menemukan fakta hukum berupa Akta Pembebanan Hak Tanggungan (untuk selanjutnya disebut APHT) dan Surat Kuasa Membebankan Hak Tanggu-ngan (untuk selanjutnya disebut SKMHT) yang objek perjanjiannya adalah utang-piutang uang yang dilakukan perusahaan multiguna. Hal ini bertentangan dengan Pengaturan Perusahaan multiguna yang dewasa ini diatur secara lex specialis.

Pembiayaan merupakan bagian dari proses peningkatan ekonomi yang juga terkait dengan bisnis. Terkait itu artinya tentu ada suatu resiko yang dimungkinkan timbul, sehingga perlu adanya mitigasi yang di laksanakan oleh lembaga pembiayaan berupa jaminan. Mitigasi resiko

\footnotetext{
${ }^{2}$ https://adira.co.id/produk-multiguna-maxijaminan-sertifikat-rumah/ diakses pada tanggal 10 juni 2018

${ }^{3}$ https://www.mpmfinance.com/content/detail/pembiayaan-properti diakses pada tanggal 20 Juni 2018.

${ }^{4}$ https://solusipinjaman.com/tabel-angsuran-bfifinance-jaminan-sertifikat-rumah/\#.Wyr-CqczbIU diakses pada tanggal 20 juni 2018.
} 
tersebut untuk melindungi Perusahaan Pembiayaan dari kemungkinan yang terjadi manakala debitur melakukan wanprestasi atau kredit macet. Pada prakteknya cara mitigasi resiko di perusahaan multiguna juga ada yang menggunakan cara pembebanan jaminan hak tanggungan. Perusahaan multiguna yang memakai jaminan Sertipikat Hak Atas Tanah bertentangan dengan ketentuan Pasal 18 ayat (2) POJK No. 29/POJK.05/2014. Pasal 18 ayat (2) POJK No. 29/POJK.05/2014 tertulis sebagai berikut:

(2)."Mitigasi Risiko pembiayaan sebagaiamana dimaksud pada ayat (1) dapat dilakukan dengan cara:

a. ... asuransi kredit ...;

b. ...barang yang dibiayai atau barang yang menjadi agunan dari kegiatan pembiayaan melalui ... asuransi; dan/atau

c. melakukan pembebanan jaminan fidusia atas barang yang dibiayai atau barang yang menjadi agunan dari kegiatan pembiayaan".

Norma dalam Pasal 18 ayat (2) POJK No. 29/POJK.05/2014 membatasi terkait sistem penghindaran resiko jika terjadi kredit macet, asumsinya manakala ditemukan fakta hukum yang tidak sesuai dengan norma tersebut maka terjadi penyimpangan. Namun penormaan tersebut menjadi tidak mencerminkan kepastian hukum ketika secara otentik dijelaskan bahwa mitigasi resiko tersebut dapat dilakukan dengan cara diluar ketentuan Pasal 18 ayat (2). Sehingga membuka ruang bagi pihak-pihak yang melakukan praktek pembiayaan oleh perusahaan multiguna untuk menggunakan mitigasi resiko diluar norma tersebut.

Hukum menurut Herman J. Pieterson adalah bangunan normatif. Herman J. Pieterson sebagaiamana tertulis dalam FX. Adji Samekto mengemukakan hukum sebagai "instrumen of the state or polis concerned with justice, with rule of conduct to regulate human behaviour" menurut terjemahan FX. Adji Samekto, "Hukum merupakan instrumen untuk menegakkan keadilan yang wujudnya berupa pedoman perilaku dengan fungsi fundamental mengatur manusia". Manakala hukum yang menjadi instrumen untuk menegakkan keadilan belum mencerminkan kepastian hukum maka tidak ada keadilan.

\subsection{Rumusan Masalah}

Berdasar uraian tersebut, maka dapat ditemukan beberapa Rumusan Masalah berikut ini :

1. Apakah perjanjian pembiayaan oleh perusahaan multiguna dapat dikualifikasikan sebagai perjanjian kredit?

\footnotetext{
${ }^{5}$ FX. Adji Samekto, Justice Not For All Kritik Terhadap Hukum Modern dalam Prespektif Studi Hukum Kritis, Genta Press, Yogyakarta, 2008, hlm. 8 .
} 
2. Apa karakteristik perjanjian pembiayaan oleh perusahaan multiguna di Indonesia?

3. Apa akibat hukum jika Perusahaan Pembiayaan multiguna menggunakan perjanjian jaminan pembebanan hak tanggungan?

\section{METODE PENELITIAN}

Dasar pemikiran argumentasi pada penelitian ini adalah Ilmu Hukum. Metode penelitian ilmu hukum pada dasarnya adalah metode penelitian hukum normatif, khususnya metode interpretasi dan kontruksi hukum, terbawa oleh karakternya sebagai ilmu praktis normologis, sesungguhnya secara metodologis merupakan dialektika normologi dan nomologi. ${ }^{6}$ Terkait itu sehingga tipe penelitian yang digunakan adalah penelitian yuridis normatif (legal research), yaitu penelitian mengenai kesesuaian penerapan pada norma-norma hukum positif terkait kepastian hukum perjanjian jaminan dengan agunan sertipikat hak atas tanah oleh perusahaan multiguna. Penelitian ini dilakukan dengan mengkaji aturan hukum yang bersifat autoritatif dan literatur sebagai konsep teori serta pendapat ahli hukum yang kemudian dihubungkan

\footnotetext{
${ }^{6}$ Herowati Poesoko, Ilmu Hukum dalam Perspektif Filsafat Ilmu, LaksBang PRESSindo, Yogyakarta, 2018, hlm. 69.
}

dengan permasalahan yang akan dianalisis. ${ }^{7}$ Penelitian ini menggunakan tiga pendekatan, yaitu pendekatan sejarah (historical approach), perundang-undangan (statute approach), dan pendekatan konseptual (conceptual approach).

\section{PEMBAHASAN}

\subsection{Kualifikasi Perjanjian Pembiayaan} Multiguna Sebagai Perjanjian Kredit Perjanjian Pembiayaan jika ditinjau dari perjanjian kebendaan merupakan perjanjian pokok begitu juga dengan perjanjian kredit, namun untuk mengkualifikasikannya sebagai perjanjian kredit tidaklah serta-merta disamakan dengan perjanjian kredit karena lahirnya pembiayaan multiguna dengan kredit tidak dengan tujuan yang sama. Terkait itu perlu melihat dari tujuan lahirnya pembiayaan multiguna, prinsipnya dan bentuk perjanjiannya.

Perkembangan lahirnya perusahaanPerusahaan Pembiayaan pada tahun 1988 yang pesat sehingga mendorong pemerintah untuk membuat kebijakan melalui Keputusan Presiden Nomor 61 Tahun 1988 tanggal 20 Desember 1988 tentang "Lembaga Pembiayaan" yang kemudian ditindaklanjuti dengan Keputusan Menteri Keuangan Republik Indonesia (KMK)

\footnotetext{
${ }^{7}$ Ibid, hlm. 29.
} 
Nomor 1251/KMK.013/1988 tanggal 20 Desember 1988 tentang Ketentuan dan Tata Cara Pelaksanaan Lembaga Pembiayaan, bidang usaha Perusahaan Pembiayaan semakin diperluas yakni selain melakukan kegiatan usaha leasing, Perusahaan Pembiayaan juga dapat melakukan kegiatan usaha Modal Ventura, Perdagangan Surat Berharga, Anjak Piutang, Usaha Kartu Kredit, dan Pembiayaan Konsumen. Namun demikian Perusahaan Pembiayaan tidak diperkenankan menarik dana secara langsung dari masyarakat.

Awal tahun 1990, Departemen Keuangan Republik Indonesia (untuk selanjutnya disebut DepKeu) melakukan deregulasi atas Perusahaan Pembiayaan dengan menerbitkan Peraturan Menteri Keuangan (untuk selanjutnya disebut PMK) Nomor 1169/KMK.01/1991 tanggal 27 November 1991 tentang Kegiatan Sewa Guna Usaha, di mana PMK ini mengatur aktivitas Perusahaan Pembiayaan yaitu sewa guna usaha secara lebih rinci. Selain mengatur aktivitas.

Melalui Peraturan Otoritas Jasa Keuangan (untuk selanjutnya disebut POJK) Nomor 29/POJK.05/2014 tanggal 19 November 2014 tentang Penyelenggaraan Usaha Perusahaan Pembiayaan, maka kegiatan usaha yang dapat dilakukan oleh Perusahaan Pembiayaan semakin diperluas dan lebih diarahkan kepada sektor produktif. Sejak berlakunya POJK Nomor
29/ POJK.05/2014 dikenal kegiatan usaha pembiayaan multiguna. Pada prinsipnya kegiatan usaha Perusahaan Pembiayaan merupakan badan usaha yang melakukan kegiatan pembiayaan untuk pengadaan barang dan/atau jasa yang dibutuhkan debitur.

Otoritas Jasa Keuangan (untuk selanjutnya disingkat OJK) dalam buku literasi keuangan yang berjudul lembaga pembiayaan seri Perguruan Tinggi yang dimaksud barang dalam hal pembiayaan oleh Perusahaan Pembiayaan dibedakan menjadi dua yaitu barang modal dan barang konsumsi. ${ }^{8}$ Barang Modal adalah "mesinmesin, traktor, truk, kapal, dan alat berat". Barang konsumsi adalah "telepon genggam, notebook, laptop, televisi, kipas angin, kulkas, sepeda motor, dan kendaraan roda empat". Sedangkan yang dimaksud dengan Jasa adalah "Jasa arsitek untuk pebangunan gedung, jasa pembiayaan untuk biaya kuliah, jasa pembiayaan untuk biaya perjalanan wisata, dan sebagainya". Tujuan didirikannya Perusahaan Pembiayaan adalah untuk turut memberikan dukungan bagi pembangunan nasional dan perkembangan ekonomi Indonesia, serta meningkatkan taraf hidup masyarakat. ${ }^{9}$

Pasal 1 angka 4 POJK No. 29/POJK.05/2014 yang dimaksud Pembiayaan Multiguna, "Pembiayaan untuk

\footnotetext{
${ }^{8}$ Ibid., hlm. 13.

${ }^{9}$ Ibid.
} 
pengadaan barang atau jasa yang diperlukan oleh debitur untuk pemakaian/konsumsi dan bukan untuk keperluan usaha (aktivitas produktif) dalam jangka waktu yang diperjanjikan". Contoh pengadaan barang atau jasa yang dapat dibiayai menggunakan pembiayaan multiguna misalnya: "telepon genggam, notebook, laptop, televisi, kipas angin, lemari es, sepeda motor, dan kendaraan roda empat". ${ }^{10}$ Artinya istilah pembiayaan multiguna di Indonesia lahir sejak diterbitkan POJK No. 29/POJK.05/ 2014. Definisi pembiayaan multiguna yang terdapat dalam peraturan OJK 29/POJK. 05/2014 Tentang penyelenggaraan usaha Perusahaan Pembiayaan, Dalam Pasal 1 angka 4 tertulis bahwa "pembiayaan multiguna adalah pembiayaan untuk pengadaan barang atau jasa yang diperlukan oleh debitur untuk pemakaian barang konsumsi dan bukan untuk keperluan usaha (aktivitas produktif) dalam jangka waktu yang diperjanjikan”. Pemberian Pembiayaan Multiguna harus digunakan untuk keperluan membeli suatu barang dan bukan untuk digunakan menambah modal atau menjalankan kegiatan usaha yang dananya bersumber dari pembiayaan multiguna. Definisi Pembiayaan Multiguna juga harus didasari oleh suatu perjanjian agar memiliki kepastian hukum terkait dengan Hak dan Kewajiban serta jangka waktu.

${ }^{10} \mathrm{Ibid}$.
Perjanjian pembiayaan multiguna merupakan perjanjian yang masuk kedalam perjanjian tidak bernama yang tidak tercantum dalam Burgerlijk Wetboek dan Kitab Undang-undang Hukum Dagang, akan tetapi konstruksi dari perjanjian pembiayaan ini didasarkan pada asas kebebasan berkontrak sebagai batu pijakan bagi Perusahaan Pembiayaan Multiguna dan Debitur. Hal ini sebagaimana dalam Pasal 1338 Burgerlijk Wetboek yang menyebutkan bahwa semua perjanjian yang dibuat secara sah berlaku sebagai undangundang bagi mereka yang membuatnya. Suatu perjanjian tidak dapat ditarik kembali selain dengan kesepakatan kedua belah pihak, atau karena alasan-alasan yang oleh undang-undang dinyatakan cukup untuk itu. Bila merujuk pada ketentuan Buku III Burgerlijk Wetboek, Perjanjian pembiayaan merupakan bentuk penjanjian khusus yang dikenal dengan istilah perjanjian konsumen, yang diantaranya mencakup :

1. penjanjian pinjam pakai habis dan

2. Perjanjian jual beli berketentuan.

Dari kententuan tersebut, penjanjian pembiayaan konsumen yang terjadi antara Perusahaan Pembiayaan dan konsumen digolongkan ke dalam "perjanjian pinjam pakai habis" sebagaimana diatur dalam Pasal 1754-1773 Burgerlijk Wetboek. Pasal 1754 Burgerlijk Wetboek menyatakan bahwa "pinjam pakai habis adalah perjanjian, dengan mana Perusahaan Pem- 
biayaan Multiguna menyerahkan sejumlah barang pakai habis kepada debitur dengan ketentuan bahwa debitur akan mengembalikan barang tersebut kepada pemberi pinjaman dalam jumlah dan keadaan yang sama". Dalam pemahaman barang habis pakai termasuk juga sejumlah uang yang dipinjamkan oleh pemberi pinjaman. Pemberi pinjaman adalah Perusahaan Pembiayaan Multiguna yang berkedudukan sebagai Perusahaan Pembiayaan Multiguna, sedangkan debitur adalah konsumen yang berkedudukan sebagai debitur. Karena barang habis pakai yang dipinjam itu sejumlah uang, maka menurut ketentuan Pasal 1765 Burgerlijk Wetboek pihak-pihak (Perusahaan Pembiayaan dan konsumen) boleh memperjanjikan pengembalian uang pokok ditambah dengan bunga.

Kemudian ketentuan Perjanjian jual beli berketentuan mengartikan perjanjian yang terjadi antara konsumen sebagai pembeli, dan dealer sebagai penjual, dengan ketentuan bahwa yang melakukan pembayaran secara tunai kepada dealer adalah Perusahaan Pembiayaan Multiguna. Perjanjian jual beli ini digolongkan ke dalam perjanjian jual beli yang diatur dalam Pasal 1457-1518 Burgerlijk Wetboek, tetapi pelaksanaan pembayaran digantungkan pada ketentuan yang disepakati dalam perjanjian pembiayaan. Menurut Pasal 1513 Burgerlijk Wetboek bahwa pembeli wajib membayar harga pembelian pada waktu dan di tempat yang ditetapkan menurut perjanjian. Ketentuan waktu dan tempat pembayaran ditetapkan dalam Perjanjian Pembiayaan Multiguna, yaitu pembayaran secara tunai oleh Perusahaan Pembiayaan multiguna ketika penjual menyerahkan nota pembelian yang ditandatangani oleh pembeli. Sunaryo mengatakan bahwa "dalam perjanjian jual beli, penjual atau dealer setuju menjual barang secara tunai kepada pembeli". ${ }^{11}$ Dealer setuju bahwa harga akan dibayar oleh Perusahaan Pembiayaan multiguna ketika surat tanda pembelian yang ditandatangani oleh pembeli diserahkan kepada perusahaan yang bersangkutan. Ketentuan perjanjian tersebut mengikat penjual dan pembeli sama mengikatnya dengan perjanjian jual beli yang terjadi antara kedua pihak. Perusahaan Pembiayaan Multiguna juga terikat karena ketika terjadi perjanjian pembiayaan konsumen, Perusahaan Pembiayaan Multiguna akan membayar harga pembelian barang yang dibeli oleh konsumen dari penjual atau dealer manapun.

Perjanjian baku secara etimologis berasal dari istilah yang dikenal dalam bahasa Inggris yaitu "standart contract". Standar kontrak merupakan perjanjian yang telah ditentukan oleh salah satu pihak yang

\footnotetext{
11 Problematika Implementasi Pembiayaan Dengan Perjanjian Jaminan Fidusia ejournal.balitbangham. go.id/index.php/dejure/article/download/433/pdf. hlm. 186. Diakses pada tanggal 26 Juli 2020
} 
lebih kuat ekonominya dan dituangkan dalam bentuk formulir.

Kontrak baku adalah "Perjanjian secara tertulis yang klausul-klausulnya dibuat sepihak dalam kontrak tersebut, bahkan umumnya kontrak tersebut sudah tercetak dalam bentuk formulir-formulir tertentu oleh salah satu pihak, yang dalam hal ini ketika kontrak tersebut ditandatangani umumnya Perusahaan Pembiayaan Multiguna dan Debitur hanya mengisikan data-data informatif tertentu saja dengan sedikit atau tanpa perubahan dalam klausulklausulnya. ${ }^{12}$

Sutan Remi Sjahdeini mengemukakan pendapat, "Perjanjian standar sebagai perjanjian yang hampir seluruh klausulklausulnya dibakukan oleh pemakainya dan pihak yang lain pada dasarnya tidak mempunyai peluang untuk menentukan atau meminta perubahan”. Adapun yang belum dibakukan hanya beberapa hal, misalnya yang menyangkut jenis, harga, jumlah, warna, tempat, dan waktu serta hal spesifik dari objek yang diperjanjikan. Sjahdeini menekankan, yang dibakukan dalam perjanjian tersebut bukanlah formulir perjanjian, melainkan klausul-klausulnya. ${ }^{13}$

Perjanjian baku dapat ditemukan pada Pasal 1 angka 10 UUPK, yang

\footnotetext{
${ }^{12}$ Munir Fuadi, hlm 76

13 Sutan Remy Sjahdeini, Kebebasan Berkontrak dan Perlindungan yang Seimbang Bagi Para Pihak dalam Perjanjian Kredit Bank di Indonesia, Institut Bankir Indonesia, Jakarta, 1993, hlm. 66.
}

menyatakan bahwa perjanjian baku adalah setiap aturan atau ketentuan dan ketentuanketentuan yang telah dipersiapkan dan ditetapkan terlebih dahulu secara sepihak oleh pelaku usaha yang dituangkan dalam suatu dokumen dan/ atau perjanjian yang mengikat dan wajib dipenuhi oleh konsumen. Memperhatikan rumusan pemahaman perjanjian baku pada Pasal 1 angka 10 UUPK ini, tampak penekanan lebih tertuju pada prosedur pembuatannya yang dilakukan secara sepihak oleh pelaku usaha, dan bukan isinya.

Keterkaitannya dengan uraian tersebut, maka dapat dikaitkan dengan ketentuan syarat sahnya suatu perjanjian yakni "sepakat" kesepakatan mereka untuk membuatnya dan mengikatkan dirinya, sebagaimana diatur pada Pasal 1320 Burgerlijk Wetboek dan berdasarkan asas konsensualisme. Penggunaan kontrak baku/ klausula baku, kebebasan berkontrak serta pemberian kesepakatan terhadap kontrak tersebut tidak dilakukan sebebas dengan melibatkan Perusahaan Pembiayaan Multiguna dan Debitur dalam menegosiasikan klausula perjanjian.

Perjanjian standar (baku), sebenarnya sudah dikenal sejak zaman Yunani Kuno. Plato (473-347), misalnya pernah memaparkan praktik penjualan makanan yang harganya ditentukan secara sepihak oleh si penjual, tanpa memperhatikan 
mutunya. ${ }^{14}$ Pada perkembangannya, tentu saja penentuan secara sepihak oleh produsen/ penyalur produk (penjual), tidak lagi sekadar masalah harga, tetapi menyangkut ketentuan-ketentuan yang lebih detail. Terkait itu, bidang- bidang yang diatur dalam perjanjian standar pun makin bertambah luas.

Secara Pengembanan hukum praktis, perjanjian baku berkembang sebagai perjanjian tertulis, dalam bentuk formulir. Perbuatan-perbuatan yang selalu terjadi secara berulang- ulang dan teratur yang melibatkan banyak orang, menimbulkan kebutuhan untuk mempersiapkan klausul-klausul perjanjian terkait pembiayaan multiguna itu terlebih dahulu, dan kemudian dibakukan dan seterusnya dicetak dalam jumlah banyak, sehingga manakala ada debitur yang datang mudah menyediakannya setiap saat jika debitur membutuhkan pembiayaan dari Perusahaan Multiguna.

Perkembangan dan perubahan masyarakat yang begitu pesat melahirkan perjanjian baku. Masyarakat sekarang merupakan kumpulan dari sejumlah ikatan kerja sama (organisasi). Perjanjian baku lazimnya dibuat oleh Perusahaan Pembiayaan. Tumbuh dan berkembangnya perjanjian baku khususnya di Indonesia

\footnotetext{
${ }^{14}$ Celina Tri Siwi Kristiyanti, Hukum Perlindungan Konsumen, Sinar Grafika, Jakarta, 2014, hlm. 138.
}

adalah karena perubahan sosial dan ekonomi.

Perjanjian baku sangat banyak digunakan pada praktek dunia bisnis khususnya oleh Perusahaan Pembiayaan multiguna yang umumnya lebih kuat ekonominya. Tujuan digunakannya perjanjian baku ini adalah untuk memberikan kemudahan (kepraktisan) bagi Perusahaan Pembiayaan Multiguna dan Debitur yang bersangkutan, biaya yang murah, efektif dan efisien karena dapat ditandatangani seketika oleh Perusahaan Pembiayaan Multiguna dan Debitur. Perjanjian baku juga merupakan salah satu bagian dari kebutuhan dalam praktik dan sudah merupakan menjadi kelazimaan kegiatan pembiayaan multiguna sehari-hari.

Perjanjian baku banyak memberikan keuntungan dalam penggunaannya, namun dari keuntungannya ada sisi lain yang menjadi kelemahan yang dikuatirkan. Hal yang perlu dikuatirkan dengan kehadiran perjanjian baku adalah karena dicantumkannya klausul eksonerasi (exemption clause) dalam perjanjian tersebut.

Klausula eksonerasi adalah "Suatu klausa dalam kontrak yang membebaskan atau membatasi tanggung jawab dari salah satu pihak yakni pelaku usaha jika terjadi wanprestasi, padahal menurut hukum, tanggung jawab tersebut mestinya dibebankan kepadanya”. Klausula eksonerasi ini menimbulkan suatu kontrak menjadi tidak 
seimbang karena hanya memberatkan pada salah satu pihak saja.

Terkait itu maka tujuan pembiayaan multiguna adalah membantu pembiayaan konsumtif berdasarkan perjanjian tidak bernama yaitu perjanjian Pembiayaan Multiguna. Perjanjian Pembiayaan Multiguna dalam POJK NO 29/POJK.05/2014 manakala ditelaah terkandung Prinsip Proporsionalitas dalam klausul-klausul yang melahirkan hak dan kewajiban. Bentuk perjanjian Pembiayaan multiguna umumnya adalah perjanjian baku. Sekalipun Perjanjian pembiayaan multiguna merupakan perjanjian pokok namun berbeda dengan perjanjian kredit karena mengandung karakteristik yang sui generis.

\subsection{Karakter Perjanjian Pembiayan Multiguna}

1. Ditinjau dari Sifat dan Jenisnya

Pengaturan Perjanjian Pembiayaan sendiri dapat ditemukan pada Bab III Perjanjian Pembiayaan Pasal 15 sampai dengan Pasal 16 POJK No. 29/POJK.05/ 2014 tentang Penyelenggaraan Perusahaan Pembiayaan. Terkait itu mengartikan makna dari perjanjian pembiayaan multiguna dapat diuraikan dengan metode kaidah hukum agar mengetahui batas-batas perumusan dengan sifat unsur-unsur yang terkandung pada pemahaman tersebut.
Kaidah hukum secara umum digolongkan menjadi 4 unsur yaitu: ${ }^{15}$

1. Perintah (gebod), "ini adalah untuk melakukan prestasi sebagai kewajiban umum";

2. Larangan (verbod), "ini adalah untuk tidak melakukan prestasi suatu kewajiban umum";

3. Pembebasan (vrijstelling, dispensasi), "ini adalah pembolehan khusus untuk tidak melakukan prestasi yang secara umum diharuskan"; dan

4. Izin (toestemming, permisi), "ini adalah pembolehan khusus untuk melakukan prestasi yang secara umum dilarang".

Sebagaimana uraian diatas maka Pasal 15 ayat (1) dan (2) secara kaidah hukum bersifat sebagai perintah namun anvulendrecht karena tidak ada keharusan dalam bentuk otentik hanya diharuskan tertulis. Perintah saling mengecualikan dengan larangan, sebab bukankah orang tidak dapat pada waktu yang bersamaan mengemban kewajiban untuk melakukan sesuatu dan kewajiban untuk tidak melakukan hal itu. Karena unsur Pasal tersebut memuat kata wajib maka berarti kaidah hukumnya sebagai perintah untuk melakukan sesuatu. Pada Pasal 15 ayat (1) dan (2) POJK 29/POJK.05/2014 berarti

15 JJ. H. Bruggink diterjemahkan oleh B. Arief Sidharta, Refleksi Tentang Hukum Pengertianpengertian Dasar dalam Teori Hukum, PT Citra Aditya Bakti, Bandung, 2011, hlm 100-101 
untuk membuat perjanjian dibuat secara tertulis. Perjanjian Pembiayaan Multiguna yang dikemudian hari dibuat secara Tertulis dapat menjadi alat bukti surat sesuai dengan Pasal 163 HIR. Hubungan keperdataan yang dituangkan secara tertulis untuk memudahkan dalam pembuktian manakala terjadi Wanprestasi. Namun perjanjian tertulis dibedakan lagi menjadi otentik dan dibawah tangan. Unsur Pasal 15 ayat (1) dan (2) POJK 29/POJK.05/2014 dan penafsiran otentiknya tidak ada perintah secara otentik.

Pada huruf i angka 4 terdapat ketentuan mengenai biaya notaris maka ada keterlibatan peran dari notaris yang berhubungan dengan perjanjian pembiayaan multiguna. Karena pada Pasal sebelumnya telah jelas tidak diharuskan atau diperintahkan untuk otentik maka peran notaris pada perjanjian pembiayaan multiguna hanya dapat pada warmerking atau Legalisasi. Menurut Irma Devita, "Waarmerking adalah surat/dokumen yang diberi tanda untuk didaftar dalam buku khusus yang dibuat oleh Notaris pada tanggal tertentu, umumnya terkadang tanggal waarmerking tidak sama dengan tanggal penandatanganan Perusahaan Pembiayaan Multiguna dan Debitur."16
2. Ditinjau dari Kedudukan Subyek dan Objeknya

Bahwa kegiatan usaha Perusahaan Pembiayaan Multiguna wajib dilakukan dengan cara:

a. Sewa Pembiayaan langsung (direct finance lease)

Perusahaan Pembiayaan membiayai pengadaan barang dari distributor/suplier untuk di sewa pembiayaan kepada debitur, Dalam hal ini dapat dikatakan bahwa Perusahaan Pembiayaan Multiguna memberikan sebuah biaya kepada debitur agar dapat membeli barang yang diinginkan oleh debitur melalui distributor/suplier dalam hal ini adalah si penjual itu sendiri. Kepemilikan atas barang objek transaksi sewa pembiayaan dalam hal perjanjian sewa pembiayaan masih berlaku, kepemilikan barang tersebut dimiliki oleh Perusahaan Pembiayaan, Meskipun barang tersebut sudah digunakan atau dimanfaatkan atau dimiliki atau dikuasai oleh debitur itu sendiri. Dalam hal ini Perusahaan Pembiayaan Multiguna wajib memastikan dalam perjanjian pembiayaan multiguna, debitur dilarang untuk menyewakan pembiayaan kembali barang yang menjadi objek perjanjian. Ketentuan ini dituangkan dalam perjanjian yang dikenal dengan perjanjian sewa pembiayaan.

\footnotetext{
${ }^{16}$ https://irmadevita.com/2012/legalisasi-danwaarmerking/
} 
b. Pembelian Dengan Pembayaran Secara Angsuran

Yang dimaksud dengan pembelian dengan pembayaran secara angsuran dijelaskan dalam Pasal 11 bahwa pembelian dengan pembayaran secara angsuran diberikan untuk pengadaan barang yang dimana kepemilikan objek pembiayaan dalam perjanjian beralih dari supplier kepada debitur. Ketentuan dalam Pasal ini tertulis pembayaran secara angsuran diberikan hanya untuk pengadaan barang bukan kepada pihak lain. Kepemilikan barang dalam hal ini akan dimiliki oleh debitur setelah barang tersebut dikatakan lunas, artinya debitur telah melakukan pembayaran sebagaimana diperjanjikan dalam perjanjian pembiayaan ini. Sebagai contoh dalam hal Perusahaan Pembiayaan Multiguna melakukan pembiayaan multiguna untuk pengadaan kendaraan bermotor dengan cara pembelian dengan pembayaran secara angsuran maka perjanjian pembiayaan multiguna tersebut wajib mencantumkan nilai uang muka. berdasarkan Pasal 16 Adapun ketentuan uang muka pembiayaan kendaraan bermotor yang diatur, yaitu:

1. Bagi kendaraan bermotor roda dua atau tiga minimal $20 \%$ dari harga jual kendaraan yang bersangkutan

2. Bagi kendaraan bermotor roda empat atau lebih yang digunakan untuk tujuan produktif minimal $20 \%$ dari harga jual kendaraan yang bersangkutan
3. Bagi kendaraan bermotor roda empat atau lebih yang digunakan untuk tujuan konsumtif minimal 25\% dari harga jual kendaraan yang bersangkutan.

c. Pembiayaan lain setelah mendapatkan persetujuan dari OJK.

Maksud dari pembiayaan lain setelah mendapatkan persetujuan dari OJK dasarkan Pasal 5 disebutkan bahwa pemilihan lagi yang dapat disetujui oleh OJK dengan ketentuan Perusahaan Pembiayaan Keharusan memiliki tingkat kesehatan keuangan dengan kondisi minimum dikatakan sehat dan tidak sedang dikenakan atau menjalankan sanksi peringatan oleh OJK. Permohonan untuk mengajukan pembiayaan lain Wajib melampirkan dokumen yang berisi uraian paling sedikit mengenai:

1. Produk yang akan dipasarkan

2. Mekanisme atau cara pembiayaan yang akan dilakukan

3. Hak dan kewajiban Perusahaan Pembiayaan Multiguna dan Debitur

4. Contoh perjanjian yang akan digunakan.

Terkait uraian tersebut diatas maka karakteristik perjanjian pembiayaan multiguna dilihat dari kedudukan subyek terdapat 3 pihak yaitu Perusahaan Pembiayaan Multiguna, Debitur dan Suplier/ Distributor. Karena barang/jasa dalam pembiayaan multiguna merupakan konsumtif 
maka dalam perjanjian jaminan pembiayaan multiguna lebih tepat dan proporsinal mengunakan pembebanan jaminan fidusia. karena objek benda dalam pembiayaan multiguna umumnya merupakan benda bergerak baik berwujud maupun tidak berwujud serta benda tidak bergerak yang tidak dapat dibebani hak tanggungan sehingga karakter khas benda tersebut sesuai dengan pengertian dari jaminan fidusia yaitu benda bergerak baik berwujud maupun tidak berwujud serta benda tidak bergerak yang tidak dapat dibebani hak tanggungan. Karakter khas ini membedakan dengan pembiayaan-pembiayaan lainnya.

3. Eksekusi Objek Jaminan Pembiayaan Multiguna

Terkait uraian sebelumnya objek pembiayaan multiguna sesuai karakternya dengan objek pembeban jaminan fidusia. Mengingat objek jaminan fidusia secara universal adalah barang bergerak yang tidak terdaftar, maka sudah sewajarnya dibuat dalam bentuk akta otentik yang dapat menjamin kepastian hukum berkenaan dengan objek jaminan fidusia.

Undang-Undang Jaminan Fidusia mewajibkan pula agar setiap benda yang dijadikan jaminan dalam suatu perjanjian fidusia harus didaftarkan di kantor pendaftaran fidusia yang berada di Jakarta. Guna menjamin adanya kepastian hukum.

Kewajiban tersebut termasuk juga bagi benda yang berada di luar wilayah
Indonesia yang dijaminkan secara fidusia. Keberadaan pendaftaran tersebut menjadi landasan lahirnya Sertifikasi jaminan Fidusia yang sama dengan Putusan Pengadilan yang "inkracht van gewijsde" yaitu sama-sama mempunyai kekuatan eksekutorial dengan dicantumkannya katakata "Demi Keadilan Berdasarkan Ketuhanan Yang Maha Esa”. Oleh karena itu pula, manakala debitur cidera janji, Untuk menjual Benda yang menjadi objek Jaminan fidusia atas kekuasaannya sendiri (parate eksekusi) merupakan hak penerima fidusia.

Sebelum dikeluarkannya UndangUndang No.42 Tahun 1999 perjanjian fidusia dilakukan di bawah tangan dan akta Notaris. Setelah dikeluarkannya UndangUndang Jaminan Fidusia, berdasarkan ketentuan Pasal 5 ayat (1) bentuk perjanjian fidusia harus dibuat dengan Akta Notaris dalam Bahasa Indonesia. Alasan UndangUndang menetapkan akta bentuk Notaris adalah:

a. Akta Notaris adalah akta otentik sehingga memiliki kekuatan pembuktian sempurna.

b. Objek Jaminan Fidusia secara universal adalah benda bergerak.

c. Undang-undang melarang adanya fidusia ulang.

Istilah Perjanjian jaminan fidusia dengan Akta Notaris oleh pembentuk Undang-Undang Jaminan Fidusia harus 
ditafsirkan secara otentik sebagai norma hukum yang memaksa (dwingenrecht) bukan aanvulendrecht, artinya manakala perjanjian jaminan fidusia dilakukan selain dalam bentuk Akta Notaris, secara yuridis perjanjian jaminan fidusia tersebut tidak pernah ada. Hal ini menguatkan proses terjadi jaminan fidusia manakala telah dilakukan pendaftaran di Kantor Pendaftaran Fidusia.

Cara pelaksanaan eksekusi terhadap benda yang menjadi objek jaminan fidusia telah diatur dalam Pasal 29 Ayat (1) UU No. $42 / 1999$ tersebut di atas, dimana salah satunya adalah dengan cara pelaksanaan titel eksekutorial sebagaimana dimaksud dalam Pasal 15 Ayat (2) UU No. $42 / 1999$ oleh penerima fidusia. Menurut pendapat Trisadini Prasastinah Usanti dan Leonora Bakarbessy, Pasal 15 UU No. 42/1999 tersebut terkandung makna 2 cara eksekusi, yaitu: ${ }^{17}$

a. Eksekusi dengan menggunakan titel eksekutorial adalah eksekusi tersebut langsung dapat terlaksana melalui pengadilan dibawah pimpinan ketua pengadilan negeri atau harus ada fiat eksekusi dari ketua Pengadilan Negeri karena sertifikat fidusia dianggap sama dengan putusan pengadilan yang

17 Usanti, Trisadini Prasastinah, and Leonora Bakarbessy, Buku Referensi Hukum Perbankan, Cet. 2, Revka Petra Media Surabaya, 2014 mempunyai kekuatan hukum tetap (in kracht van gewijsde) dan bersifat final serta mengikat pada pihak untuk melakanakan putusan tersebut.

b. Makna parate eksekusi, yang menjadi salah satu ciri dari jaminan kebendaan.

Menurut A. A. Andi Prajitno, terjemahan bebas dari Parate Eksekusi adalah "Perusahaan Pembiayaan Multiguna melaksanakan hak atas kekuasaannya sendiri untuk menjual benda jaminan secara bebas seperti milik sendiri, manakala debitur tidak menepati janji atau wanprestasi", 18

Pelaksanaan eksekusi atas objek jaminan fidusia, berdasarkan Pasal 32 UU No. 42/1999, bersifat tertutup, maksudnya adalah tidak dimungkinkan diperjanjikan dengan cara lain, selainnya yang diatur dalam Pasal 29 dan 31 Undang-Undang tersebut, dengan ancaman (Null and Void).

Terkait itu ada 2 janji yang dilarang dalam pelaksanaan eksekusi objek jami nan fidusia yaitu: ${ }^{19}$

a. Janji melaksanakan eksekusi terhadap benda yang menjadi objek jaminan fidusia dengan cara yang bertentangan dengan Pasal 29 dan 31 UU No. 42/1999 (vide Pasal 32 UU No. 42/1999), dan

\footnotetext{
18 A.A. Prajitno, Hukum Fidusia,: Selaras Malang, 2010, hlm.60

${ }^{19}$ Ibid.
} 
b. Janji yang memberi kewenangan kepada penerima fidusia (Perusahaan Pembiayaan Multiguna) untuk memiliki benda yang menjadi objek jaminan fidusia, manakala debitur cidera janji (vide Pasal 33 UU No. 42/1999).

\subsection{Akibat Hukum Pembebanan Hak Tanggungan Dalam Perjanjian Multiguna}

"Pasal 18 ayat (1) POJK" Perusahaan Pembiayaan Multiguna wajib melakukan Mitigasi risiko pembiayaan. Menurut ketentuan pada Pasal 18 ayat (2) POJK Mitigasi risiko salah satu diantaranya yaitu pembebanan jaminan fidusia atas barang yang dibiayai atau barang yang menjadi agunan dari kegiatan pembiayaan. Pembebanan Jaminan Fidusia tidak dapat berdiri sendiri tanpa adanya perjanjian sebelumnya atau perjanjian pokok yang mendahuluinya. Menurut hukum kebendaan perjanjian pembebanan jaminan fidusia merupakan accesoir dari perjanjian pokok dalam hal ini perjanjian pembiayaan multiguna.

Artinya Manakala secara pengembanan hukum praktis atau fakta hukum ada pembiayaan multiguna dengan Pembebanan Hak Tanggungan merupakan hal yang menyimpang. Perbuatan penyimpangan tersebut menimbulkan perjanjian itu (Null and Void). Batal mempunyai implikasi arti sebagai berikut:
1. Tidak berlaku atau tidak sah, perjanjian itu dinyatakan;

2. Tidak dapat dilangsungkan; tertunda; tidak jadi: rapat kemarin terpaksa karena yang hadir kurang dari ketentuan;

3. Tidak berhasil; gagal.

Dengan demikian, batal atau menyatakan batal artinya perjanjian yang pernah disetujui bersama tidak sah atau dianggap tidak pernah terjadi. Sedangkan (Null and Void) adalah kebatalan yang terjadi berdasarkan undang-undang, mempunyai implikasi perbuatan hukum tersebut dianggap tidak pernah terjadi.

Kontrak yang tidak boleh dijalankan atau dilakukan prestasi sama sekali merupakan kontrak yang batal demi hukum (Null and Void) (void). Bila sebuah kontrak dinyatakan (Null and Void) sejak awal (Latin: ab initio) berarti Perusahaan Pembiayaan Multiguna dan Debitur baik Perusahaan Pembiayaan Multiguna maupun Debitur harus meletakkan segala sesuatu seperti semula sebelum kontrak. Kontrak (Null and Void) bila salah satu pihak tidak memiliki kapasitas untuk melakukan kontrak, berdasarkan pada suatu kesalahan, atau melawan hukum.

Pada bab sebelumnya telah dibahas bahwa subyek yang terkait dengan perjanjian pembiayaan mutliguna ada 3 (tiga) yaitu Debitur, Perusahaan Pembiayaan multiguna, Suplier/Distributor. 
Akibat hukum manakala perjanjian accesoir Pembebanan Hak Tanggungan dibatalkan tentu sekilas hanya akan merugikan pihak Perusahaan Pembiayaan Multiguna. Namun jika melihat konsep dari perjanjian accesoir itu lahir karena adanya perjanjian pokok dalam hal ini perjanjian Pembiayaan Multiguna. Secara Norma terkandung makna dari prinsip proposional dalam perjanjian pembiayaan multiguna yang salah satu diantaranya yaitu pembebanan jaminan fidusia. Artinya manakala ada perjanjian jaminan terkait pembiayaan multiguna maka didalam perjanjian pokoknya wajib tertulis klausul dengan mengunakan mitigasi resiko sesuai pasal Pasal 15 POJK NO 29/POJK.05/2014 Juncto Pasal 18 Ayat (2) yaitu pembebanan jaminannya menggunakan jaminan fidusia.

Manakala Perjanjian Accesoirnya itu pembebanan Hak Tanggungan dan itu penyimpangan hukum dan batal demi hukum pihak distributor dan debitur dirugikan sehingga perjanjian terkait pembiayaan multiguna tersebut tidak dapat mencerminkan kepastian hukum. Terkait penyimpang hukum tersebut secara operasional maka Perusahaan Pembiayaan Multiguna dapat dikenakan sanksi oleh OJK sebagaiman tertulis dalam Pasal 61 ayat (1) POJK. No. 29 Tahun 2014.

Akibat hukum bagi Perusahaan Pembiayaan multiguna yang melakukan pembebanan jaminan hak tanggungan jika melihat dari "Pasal 61 POJK No 29 Tahun 2014" akan diberikan surat pemberitahuan oleh OJK untuk melakukan pemenuhan sesuai dengan mitigasi resiko yang telah diatur. Manakala tidak memenuhi sebagaimana dimaksud pada Pasal 61 ayat (1) POJK. No. 29 Tahun 2014, Perusahaan Pembiayaan Multiguna dikenakan sanksi administratif secara bertahap berupa: Peringatan; Pembekuan Kegiatan Usaha; dan Pencabutan izin usaha.

Penafsiran aturan-aturan Penyelenggaraan Perusahaan Pembiayaan Multiguna seharusnya memberikan kepastian hukum agar tidak menjadi celah hukum bagi pihakpihak yang terkait. Menurut Herlien Budiono bahwa kepastian hukum merupakan ciri yang tidak dapat dipisahkan dari hukum, Paling fundamental untuk norma hukum tertulis. Hukum tanpa nilai kepastian akan kehilangan makna karena tidak dapat dijadikan sebagai pedoman perilaku bagi semua orang. ${ }^{20}$ Van Apeldoorn mengatakan bahwa kepastian hukum memiliki dua segi yaitu dapat ditentukannya hukum dalam hal yang konkret dan keamanan hukum. Terkait ini berarti pihak yang mencari keadilan ingin mengetahui apa yang menjadi hukum dalam suatu hal tertentu sebelum ia mengehadapi sengketa agar mendapatkan perlindungan bagi

\footnotetext{
${ }^{20} \mathrm{http} / / /$ repository.usu.ac.id/bitstream/handle/123456 789/67042/Chapter\%20I.pdf?sequence=4\&isAllo wed $=y$ diakses pada 21 Juni 2018
} 
Perusahaan Pembiayaan Multiguna dan Debitur dalam peradilan. ${ }^{21}$

Kekaburan dari penafsiran otentik (vagenorm) mitigasi resiko membuat Perusahaan kurang cermat dalam membuat perjanjian sehingga terdapat fakta Pembebanan Hak Tanggungan yang secara Prinsip Proporsionalitas tidak sesuai dengan objek pembiyaan yang sifatnya konsumtif dalam kaitannya dengan pembiayaan multiguna akan merugikan pihak Perusahaan Pembiayaan Multiguna sendiri Karena Perjanjian Pembebanan Hak Tanggungan dalam Pembiayaan multiguna tidak memiliki kekuatan hukum sehingga tidak menimbulkan kepastian hukum. Artinya dalam pembiayaan multiguna berdasarkan karakternya dan prinsip proporsionalitas manakala obyeknya adalah benda konsumtif maka proporsionalitasnya pembebanan jaminannya adalah benda konsumtif yang hanya dapat dibebankan oleh jaminan fidusia bukan jaminan Hak Tanggungan.

Ketika Perjanjian jaminan tersebut (Null and Void) maka tidak timbul suatu perikatan sehingga manakala debitur wanprestasi kemudian dilakukan pembatalan perjanjian pembebanan hak tanggungan tersebut secara perdata debitur tidak wajib memberikan objek benda yang dijaminkan untuk pelunasan karena hubungan hukumnya hanya terletak pada

\footnotetext{
${ }^{21}$ Ibid.
}

pembiayaan. Perusahaan Pembiayaan Multiguna dapat diberikan sanksi secara administrasi. Terkait Distributor/Suplier tidak dapat jaminan kepastian pelunasan atas barang konsumtif yang dinikmati oleh debitur.

\section{KESIMPULAN}

Berdasarkan analisa sebagaimana dijelaskan dalam bab sebelumnya maka adapun kesimpulan yang didapat sebagai berikut:

1. Kualifikasi perjanjian pembiayaan multiguna tidak dapat dimasukkan sebagai perjanjian kredit, hal ini dikarenakan tujuan pembiayan multiguna dan prinsip proporsionalitasnya berbeda meskipun sama-sama perjanjian pokok. Merujuk pada pemahaman pembiayaan multiguna itu sendiri, pembiayaan pengadaan barang dan jasa pada dasarnya diberikan oleh perusahaan untuk kebutuhan konsumtif debitur. Perjanjian Kredit sendiri terdiri dari perjanjian kredit produktif dan perjanjian kredit konsumtif. Jika merujuk pada pemahaman perjanjian pembiayaan multiguna maka tidak memenuhi kualifikasi perjanjian kredit.

2. Karakterisitik perjanjian pembiayaan multiguna di Indonesia dapat dilihat dari cirikhas dari perjanjian itu sendiri, pertama sifatnya dari sudut pandang kaidah hukum primer sebagai perintah 
dan jenis perikatannya yang merupakan perikatan berketentuan. Kedua, dilihat dari Kedudukan hukum antara subyek dan obyeknya dengan melihat metode pembiayaan, mempunyai karakter yang khas membedakan dengan kredit perbankan subyeknya terdiri tiga yaitu, Perusahaan Pembiayaan Multiguna, Debitur, dan Suplier/Distributor. Objek bendanya memiliki karakter yang khas yaitu benda bergerak baik berwujud maupun tidak berwujud dan benda tidak bergerak yang tidak dapat dibebani hak tanggungan karakter khas ini sejalan dengan pengertian jaminan fidusia. Sifat Khas tersebut secara eksekusi jaminannya juga membedakan dengan yang lain.

3. Akibat Hukum Perusahaan Pembiayaan Multiguna Menggunakan Perjanjian Jaminan Pembebanan Hak Tanggungan ada 3 unsur yaitu Pertama Unsur idiil perjanjiannya (Null and Void), hal ini dikarenakan perjanjian tersebut tidak sesuai dengan ketentuan sahnya perjanjian sebagaimana diatur dalam Pasal 1320 Burgerlijk Wetboek mengenai ketentuan objektif yaitu adanya suatu sebab yang yang diperkenankan. Suatu sebab yang diperkenankan yang dimaksud adalah suatu perjanjian yang dibuat tidak bertentangan dengan peraturan perundang-undangan. Kedua Unsur Operasional akibat hukum bagi
Perusahaan Pembiayaan multiguna yang melakukan pembebanan jaminan hak tanggungan dikenakan sanksi. Manakala tidak memenuhi sebagaimana dimaksud pada Pasal 61 ayat (1) POJK No. 29 Tahun 2014, Perusahaan Pembiayaan dikenakan sanksi administratif secara bertahap berupa: a. Peringatan, b. Pembekuan Kegiatan Usaha dan c. Pencabutan izin usaha. Secara kelembagaan jaminan juga berbeda manakala hak tanggungan dibawah Badan Pertanahan/ Agraria Tata Ruang sedangkan Fidusia melalui kemenkumham Ketiga Unsur Aktual perjanjian harus menganut prinsip proporsionalitas agar terjadi suatu keseimbangan antara debitur dengan Perusahaan Pembiayaan multiguna dan tidak mengacu pada penafsiran otentik aturan mitigasi resiko Pasal 18 ayat (2) POJK No. 29/ POJK. 05/2014. Karena penafsiran otentik pasal tersebut tidak memberikan kepastian hukum.

\section{DAFTAR PUSTAKA}

\section{BUKU}

Adji Samekto, FX., Justice Not For All Kritik Terhadap Hukum Modern dalam Perspektif Studi Hukum Kritis, Genta Press. Yogyakarta, 2008 , 
Achmad Ali, Menguak Teori Hukum (Legal

Theory) \& Teori Peradilan

(Judicialprudence) Termasuk

Undang-Undang (Legisprudence)

Volume I Pemahaman Awal,

Kencana Prenada Media Group.

Jakarta, 2010.

Agus Yuda Hernoko, Azas Proporsionalitas dalam Kontrak Komersil, Laksbang Mediatama. Yogyakarta, 2008.

Celina Tri Siwi Kristiyanti, Hukum Perlindungan KonsumenSinar Grafika, Jakarta, 2014.

Dominikus Rato, Mencari, Menemukan dan Memahami Hukum, Laksbang Justitia, Surabaya, 2010.

Elly Erawati dan Herlien Budiono, , Penjelasan Hukum Tentang Kebatalan Perjanjian, Gramedia, Jakarta, 2010

Hasanudin Rahman, Aspek-Aspek Hukum Pemberian Kredit Perbankan Di Indonesia, Citra Aditya Bakti, Bandung : 1998.

Henry Cambell Black, Black's Law Dictionary, West Publishing Co., United States of America, 1979.

Henry Soelistyo, Pelanggaran Hak Cipta dan Etika, Kanisius, Yogyakarta: 2011 .
Herowati Poesoko, Dinamika Hukum Parate Executie Obyek Hak Tanggungan, Aswaja Pressindo, Yogyakarta, 2013. , Ilmu Hukum dalam Perspektif Filsafat Ilmu, LaksBang PRESSindo, Yogyakarta, 2018.

JJH, Bruggink, Refleksi Hukum, Terjemahan Arif Sidharta, Aditya Bhakti. Bandung: 1995.

Kasmir, Bank dan Lembaga Keuangan Lainnya, Edisi Revisi, PT. Raja Grafindo Persada, Jakarta, 2008.

Peter Mahmud Marzuki, Penelitian Hukum, Kencana Prenada Media Group. Jakarta, 2005.

Rudyanti Dorotea Tobing, Hukum lembaga Pembiayaan Asas Keadilan dalam Perjanjian Pembiayaan, Laksbang pressindo, Surabaya, 2017.

Riky Rustama, Hukum Jaminan, UII Perss Yogyakarta, 2017

Salim H.S., Hukum Kontrak : Teori dan Teknik Penyusunan Kontrak., Sinar Grafika, Jakarta, 2003.

Subekti, Hukum Perjanjian, Intermasa. Jakarta, 1990, 
INTERNET

https://adira.co.id/produk-multiguna-maxijaminan-sertifikat-rumah/

https://www.mpm-finance.com/content/ detail/pembiayaan-properti

http://lib.ui.ac.id/file?file=digital/20306259 -S42215erusahaan\%20pembiayaan. pdf

https://solusipinjaman.com/tabel-angsuranbfi-finance jaminan-sertifikatrumah/\#.Wyr-CqczbIU

http://repository.usu.ac.id/bitstream/handle/ 123456789/67042/Chapter\%20I.pdf ?sequence $=4 \&$ is Allowed $=\mathrm{y}$

https://yancearizona.net/2008/04/13/apaitu-kepastian-hukum/

https://media.neliti.com/media/publications/ 176721-ID-implementasi-asas-asasumum-hukum-kebend.pdf

Tahapan Fiat Executie Hak Tanggungan https://litigasi.co.id/tahapan-fiateksekusi-hak-tanggungan.

https://ejournal.balitbangham.go.id/index.p hp/dejure/article/download/433/pdf.
PERATURAN

PERUNDANGUNDANGAN

Undang-Undang Republik Indonesia Nomor 21 Tahun 2011 Tentang Otoritas Jasa Keuangan.

Undang-Undang Republik Indonesia Nomor 10 Tahun 1998 Tentang Perubahan Atas Undang-Undang Nomor 7 Tahun 1992 Tentang Perbankan

Undang-Undang Republik Indonesia Nomor 4 tahun 1996 Tentang Hak Tanggungan

Peraturan Presiden Republik Indonesia Nomor 9 Tahun 2009 Tentang Lembaga Pembiayaan.

Peraturan Otoritas Jasa Keuangan Nomor 29/POJK.05/2014 Tentang Penyelenggaraan Usaha Perusahaan Pembiayaan.

\section{BIODATA SINGKAT PENULIS}

Syahrul Ramadhan menyelesaikan pendidikan Magister Kenotariatan pada Program Studi Kenotariatan Pasca Sarjana Fakultas Hukum Universitas Jember tahun 2020. 